12th LUMEN International Scientific Conference Rethinking Social Action. Core Values in Practice | RSACVP 2019 | 15-17 May 2019 | lasi - Romania

\title{
Improve Wastewater Treatment Methods from Brewing Industry
}

\author{
Casen PANAITESCU
}

https://doi.org/10.18662/lumproc.169

How to cite: Panaitescu, C. (2019). Improve Wastewater Treatment Methods from Brewing Industry. In C. Ignatescu (ed.), 12th LUMEN International Scientific Conference Rethinking Social Action. Core Values in Practice, 15-17 May 2019, Iasi - Romania (pp. 232-238). Iasi, Romania: LUMEN Proceedings. https://doi.org/10.18662/lumproc.169 


\title{
Improve Wastewater Treatment Methods from Brewing Industry
}

\section{Casen PANAITESCU ${ }^{1}$}

\begin{abstract}
Analyzing the current waste water treatment possibilities in the brewing industry, finds that an extra amount of oxygen in the system can lead to improved water quality. Also, the need to improve the anaerobic stage may be a technically and economically efficient method. Taking into account these two premises, the paper presents the results obtained by applying the two methods of treatment, and present a comparative study of the water quality before and after the improvement of the purification process.
\end{abstract}

Keywords: Wastewater; treatment; aerob; anaerob.

\section{Introduction}

Anaerobic reactors have been used primarily for the treatment of industrial wastewater. Research has shown that anaerobic systems such as the UASB and the anaerobic filter can successfully treat highly contaminated industrial wastewater as well as those with a low pollutant load $[1,2]$.

Therefore, most of the water is heated before treatment, consuming up to $30 \%$ of the energy produced. The main objective is to reduce the cost of waste water treatment and to minimize the amount of excess sludge resulting from the processes $[3,4,5]$. Anaerobic decomposition is used when decomposition of organic substances in wastewater requires long decomposition periods (greater than 10 days) [6]

Once the sludge is subjected to decomposition processes, the amount of organic material decreases due to the destruction of volatile substances. Thus, their volume and weight decreases. The content of solids in most sludge reaches somewhere at $45-55 \%$. Anaerobic bacteria destroy approximately $80 \%$ of the amount of organic waste from the input of a

\footnotetext{
1 Petroleum-Gas University of Ploieşti, Romania, Ploiesti, Romania, cpanaitescu@upgploiesti.ro 
sewage treatment plant. About $30 \%$ of waste is removed in the settling basins, and almost $50 \%$ is sinuated and transformed into new bacterial cells Anaerobic slurry biomass slurries are commonly used to treat industrial wastewater to degrade primary and secondary sludge [9-12]. Following the purification process in the anaerobic reactors, biogas is obtained [6, 13-15].

Anaerobic fermentation pools with fixed biomass use a medium such as plastic or stones as the surface where bacteria develop as a biofilm.

When passing waste water over this medium, pollutants are absorbed and adsorbed on the surface of biofilms and degraded.

Despite the fact that anaerobic decompositions offer a multitude of positive features, unfortunately they also have the disadvantage of process instability due to microbiological load and decomposition processes $[6,7]$.

The normal value of COD for wastewater from beer plants is approximately $2800 \mathrm{mgO}_{2} / \mathrm{l}$, (with a discharge rate of 51 / 1 of beer.) For example, if all yeast production is discharged into sewage sewers, loading in COD will increase by $\sim 35 \%$.

In addition to this increase in COD load, wastewater treatment plants are not designed to treat large quantities of yeast. Yeast leads to negative aspects in the operation of the treatment plant (oxygen depletion of the aeration, foam appearance, sludge degradation both anaerobic and aerobic, increase in energy and chemical consumption, etc.).

Some products (such as glue, soap etc.) and cleaning products can also have a high COD.

This paper deals with the treatment of the waste water in anaerobic reactor at Beer Factory. This study took into account the provisions of Government Emergency Ordinance (GEO) 195/2005 on environmental protection [8] and O.U.G. no. 152/2005 on Integrated Pollution Prevention and Control. According to the provisions of the Emergency Ordinance no. 195 / 22.12.2005 on environmental protection, natural and legal persons have the obligation to request and obtain the regulatory acts from the environmental protection authorities, respectively environmental permit/licence / agreement and to comply with the operational requirements in order to protect the environment environment.

\section{Research Methods. Methodology}

From the conditioning basin, the waste water is pumped to the UASB reactors. The reactor is a concrete and HDPE (protection) pool containing an anaerobic slurry, waste water and biogas. Wastewater enters the reactors through the bottom and passes through an anaerobic granular 
bed of biomass where biological conversion processes and biogas formation take place.

In the separator at the top of the reactor three phases are separated: biogas, biomass and purified waste water. The biogas comes out of the reactor through the upper pipe.

From the reactor, the biogas is transported under pressure to the biogas cleaning system. After the cleaning procedure, the sludge flows gravitationally the resulting aeration tank. The resulting biogas is accumulated in a balloon designed to provide a relatively constant flow of biogas. The scrubber resulting from the scrubber is wet, therefore it is passed through a biogas dryer with glycol and finally the biogas is burned or mixed with methane and burnt in the boiler.

In the laboratory of the wastewater treatment plant, an experiment was carried out which had as main purpose the improvement of the quality of the anaerobic sludge and implicitly of the wastewater treatment process.

Materials and equipment used in the experiment:

- anaerobic sludge taken from the reactor of the treatment plant;

- model inoculum, consisting of selected yeast bacteria;

- experimental sludge;

- experimental installation (Figure 1);

- $\mathrm{pH}$ meter to determine $\mathrm{pH}$, temperature and redox potential.

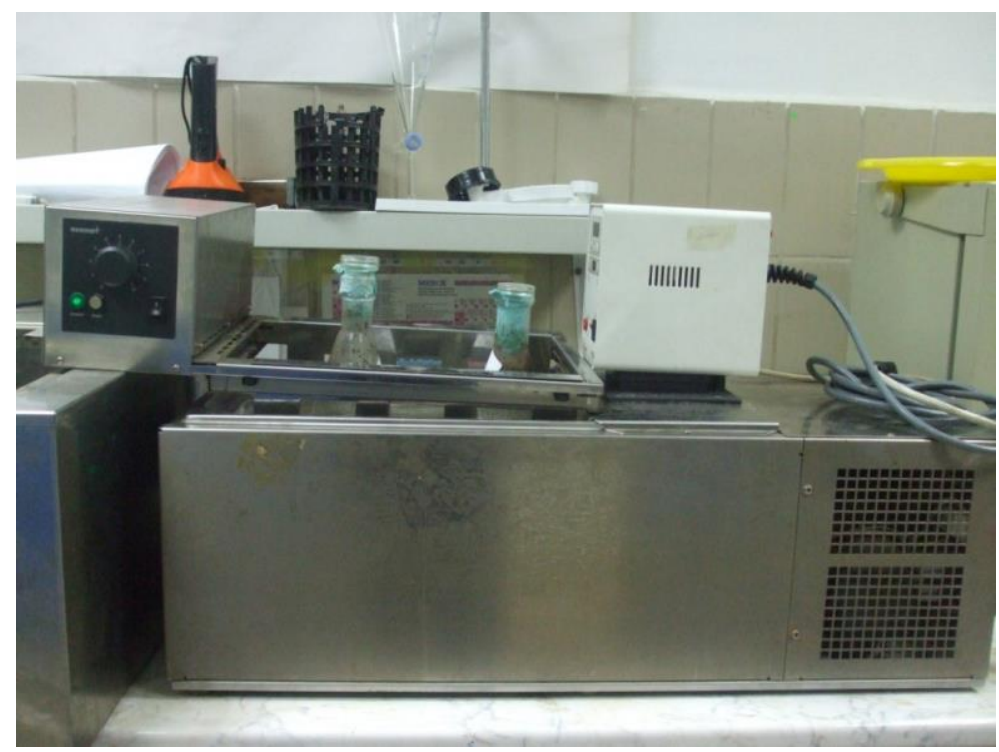

Figure 1. The experimental installation. 
Measurements made:

units,

- $\mathrm{pH}$ : daily assessment with $\mathrm{pH}$ meter, measuring range $0 \div 14 \mathrm{pH}$

- temperature: determined daily,

- Oxidation Reduction Potential: Determined daily.

The experiment was carried out for 6 days (aprox.144 hours) and consisted of following and comparing some quality indicators of the two samples to be analyzed, carried out as follows:

- the first Erlenmayer glass, containing 1 gram of live, liquid yeast, from the beer plant and $250 \mathrm{ml}$ of sludge from the reactor of the treatment plant,

- the second Erlenmayer glass, containing 10 grams of experimental sludge, taken from the layer of $0.2 \mathrm{~m}$ and $250 \mathrm{ml}$ of sludge from the anaerobic reactor of the treatment plant.

\section{Results and discussion}

Anaerobic treatment is a microbiological process for the degradation of organic matter and is characterized by the production of biogas. Biogas consists largely of methane (60-90\%) and carbon dioxide (10-40\%). Most of the organic matter, through anaerobic degradation, turns into biogas, a relatively small part is transformed into new cellular material.

The anaerobic procedure is temperature sensitive (variations). For optimal operation, the temperature should be constant as much as possible between 30 and $37^{\circ} \mathrm{C}$.

When temperature control is not working properly or when the temperature of the waste water is too low, it is permissible that the process temperature deviates from the desired values between $25-39{ }^{\circ} \mathrm{C}$. Symptoms of an incorrect temperature will generally be correlated with undesirable $\mathrm{pH}$ deviations (Table 3)

Table 3. Impact of $\mathrm{pH}$ variation on biomass.

\begin{tabular}{|c|c|c|c|}
\hline \multicolumn{4}{|c|}{$\mathbf{p H}$ Limits } \\
\hline $6,8-7,2$ & $6,5-6,8$ şi 7,2-7,8 & $5,5-6,5$ şi 7,8-9 & $<5,5$ şi $>9,0$ \\
\hline $\begin{array}{c}\text { Optimal } \\
\text { conditions }\end{array}$ & $\begin{array}{c}\text { Suboptimal, but } \\
\text { without bacterial } \\
\text { damage }\end{array}$ & $\begin{array}{c}\text { Substantial loss of } \\
\text { activity and after } \\
\text { long exposure, } \\
\text { possible damage to } \\
\text { bacteria }\end{array}$ & $\begin{array}{c}\text { Dramatic loss of } \\
\text { activity and death } \\
\text { of microorganisms }\end{array}$ \\
\hline
\end{tabular}


A temperature too high up to $42^{\circ} \mathrm{C}$ for a long time (12 hours or more) will result in partial or total killing of microorganisms. A too low temperature will inactivate the process but will not destroy the bacteria.

The samples thus performed were kept at a constant temperature of $35{ }^{\circ} \mathrm{C}$. The experimental plant was equipped with a mechanical stirrer required for sample mixing. The data obtained are shown in Table 4.

Table 4. Values obtained from the experiment

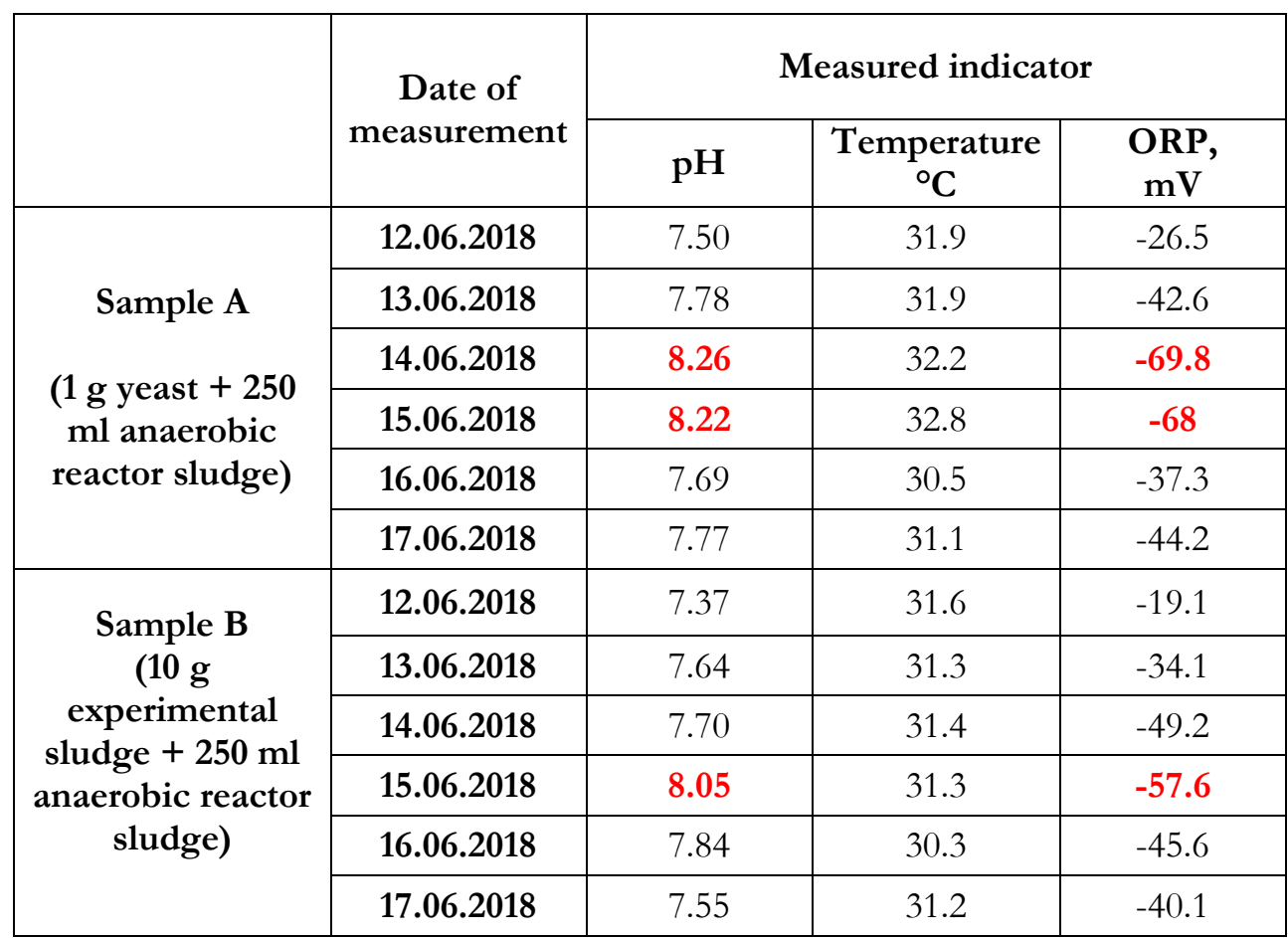

For $\mathrm{pH}$ values exceeding 8 units, $\mathrm{pH}$ correction was adjusted with $\mathrm{HCl}, 0.1 \mathrm{~N}$, following the correction, in addition to the $\mathrm{pH}$ and the redox potential of the solution. The table below shows the values obtained after $\mathrm{pH}$ correction was made. 
Table 5. Values obtained after correction of $\mathrm{pH}$.

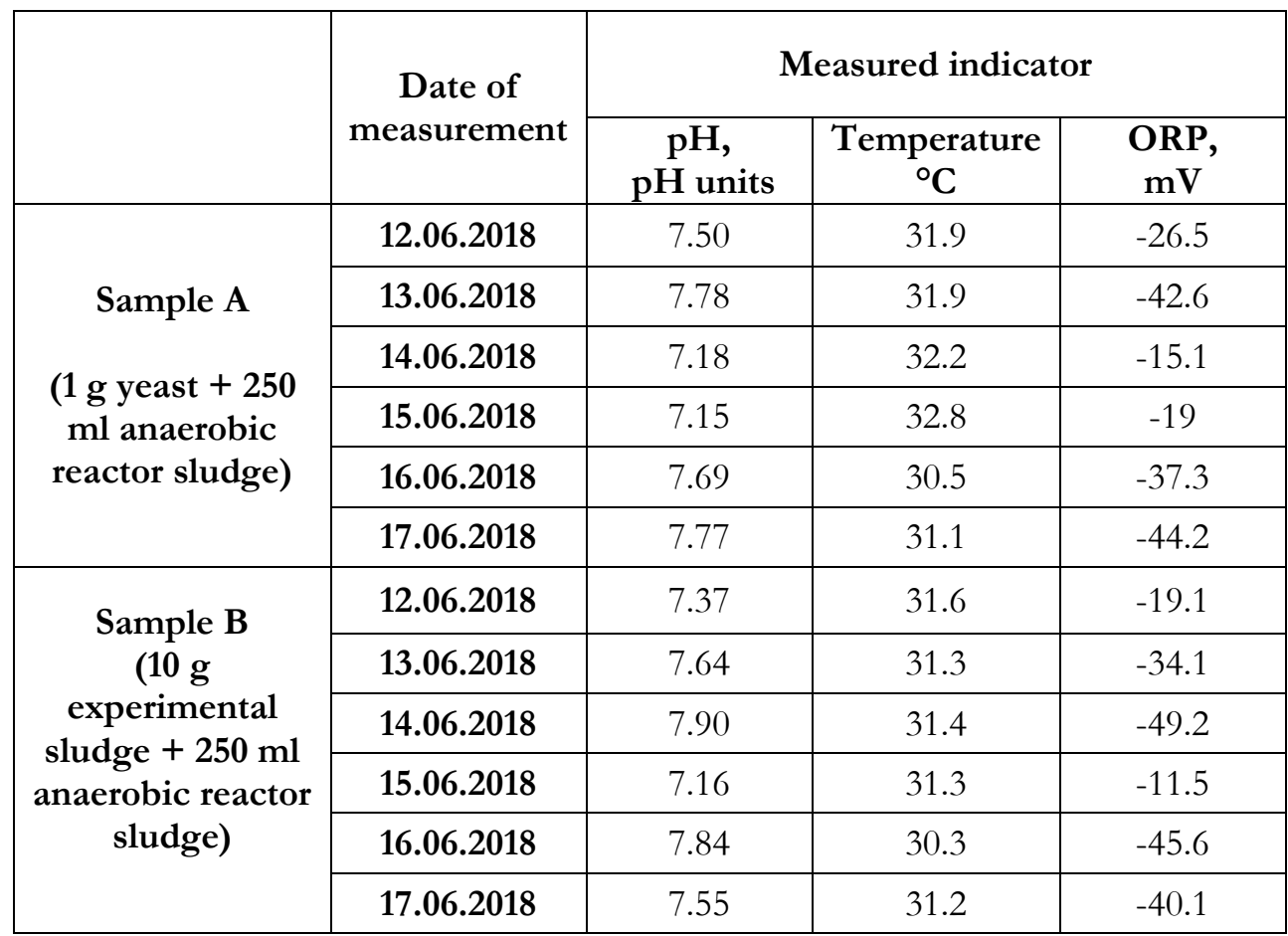

\section{Conclusions}

Overloading of anaerobic reactors can be avoided by prior laboratory studies. Thus temperature control maintained between $30-32^{\circ} \mathrm{C}$ and $\mathrm{pH}$ can lead to higher biogas qualities. It is also possible to metabolize more than $60 \%$ of the organic material.

Approximately $90 \%$ of the waste water flow comes from the production process: $42 \%$ bottling, $20 \%$ filtration, $15 \%$ fermentation and aging and 13\% boiling. Only 10\% come from other departments such as energy and treatment of water.

\section{References}

[1] Rojanschi V, Bran F, Diaconu G. Protecția si ingineria mediului. Bucuresti: Editura Economica; 2002.

[2] Panaitescu C, Petrescu MG. Research about the Corosive Effects of $\mathrm{FeCl} 3$ in the Aeration Wastewater Basin. OP Conference Series: Materials Science and Engineering. 2018;295(1),012039. 
[3] Buntner D, Spanjers H, Lier JBV. The influence of hydrolysis induced biopolymers from recycled aerobic sludge on specific methanogenic activity and sludge filterability in an anaerobic membrane bioreactor. Water Res. 2014; 51:284-292.

[4] Hafid HS, Nor'Aini AR, Mokhtar MN, Talib AT, Baharuddin AS, Kalsom MSU. Over production of fermentable sugar for bioethanol production from carbohydrate-rich Malaysian food waste via sequential acid-enzymatic hydrolysis pretreatment. Waste Manag. 2017;67:95-105

[5] Yi Q, Gao Y, Zhang H, Zhang H, Zhang Y, Yang M. Establishment of a pretreatment method for tetracycline production wastewater using enhanced hydrolysis. Chem. Eng. J. 2016;300:139-145.

[6] Michael HG. The Microbiology of Anaerobic Digesters. UK: A John Wiley \& Sons, Inc., Publication; 2003.

[7] Parawira W, Kudita I, Nyandoroh MG, Zvauya R. A study of industrial anaerobic treatment of opaque beer brewery wastewater in a tropical climate using a full-scale UASB reactor seeded with activated sludge. Process Biochemistry; 2005.

[8] http://www.unece.org

[9] Chen H, Chang S. Impact of temperatures on microbial community structures of sewage sludge biological hydrolysis. Bioresour. Technol. 2017;245:502-510.

[10] Bin M, Wang S, Cao S, Miao Y, Jia F, Du R, Peng Y. Biological nitrogen removal from sewage via anammox: Recent advances. Bioresour. Technol. 2015;200:981-990.

[11] Lew B, Tarre S, Beliavski M, Dosoretz C, Green M. Anaerobic Membrane Bioreactor (AnMBR) for Domestic Wastewater Treatment. Desalination, 2009;243(1-3):251-257.

[12] Chang S. Anaerobic Membrane Bioreactors (AnMBR) for Wastewater Treatment. Advances in Chemical Engineering and Science, 2014;4:56-61.

[13] Hulshoff PLS, de Zeeuw WJ, Velzeboer CTM, Lettinga G. Granulation in UASB-Reactor. Water Science and Technology, 1983;15:291-304.

[14] Narnoli SK, Mehrotra I. Sludge blanke of UASB reactor: mathematical simulation. Water Research. 1996;31(4):715-726.

[15] Liu Y, Xu H-L, Show K-Y, Tay J-H. Anaerobic granulation technology for wastewater treatment. World Journal of Microbiology and Biotechnology. 2002;18:99- 113 . 